\title{
Research Article \\ Effects of Posttensioning Slippage on 2-Way Spanning Concrete Slabs
}

\author{
Niall Holmes and Eoin Byrne \\ School of Civil \& Structural Engineering, Dublin Institute of Technology, Bolton Street, Dublin 1, Ireland \\ Correspondence should be addressed to Niall Holmes; niall.holmes@dit.ie
}

Received 30 January 2015; Accepted 19 March 2015

Academic Editor: Hamid Ronagh

Copyright (C) 2015 N. Holmes and E. Byrne. This is an open access article distributed under the Creative Commons Attribution License, which permits unrestricted use, distribution, and reproduction in any medium, provided the original work is properly cited.

\begin{abstract}
This paper investigates the effect of improper posttensioning of a 2-way spanning concrete slab subject to a central point load. Due to plate slippage alone, the support conditions only offered a 1-way spanning action which could have led to premature failure with dangerous consequences. Posttensioning can strengthen a flat slab against punching shear by controlling deflections and cracking under service loads compared with traditional punching shear reinforcing methods leading to more slender structures and economic solutions for longer spans. However, if the method is not properly applied, these thinner floor plates can fail in a brittle and sudden manner by punching at ultimate limit state and excessive deflection in serviceability. Concrete slabs containing traditional shear reinforcement performed adequately and demonstrated that the critical punching shear perimeter, defined as twice the depth of the slab, was confirmed from measured deflections and crack pattern analysis.
\end{abstract}

\section{Introduction}

A number of different design codes are used for punching shear [1-3]. In Ireland, the design of concrete structures follows the guidelines in [3] which are based on Model Code 1990 [4]. However, most of the formulas are empirical in nature $[5,6]$.

Generally, three factors contribute to the shear resistance of nonreinforced concrete, namely, the area of concrete in compression, the dowel action of longitudinal tensile reinforcement and the interlocking nature of the aggregates. The Eurocode 2 [1] approach for designing against punching shear failure in solid concrete slabs defines the critical control perimeter $\left(u_{1}\right)$ as shown in Figure 1 where $d$ is the mean effective depth of the slab. This perimeter should therefore be minimized, examples of which are shown in Figure 2 for different cross sections. The approach adopted in the Eurocode for the punching shear resistance of slabs without shear reinforcement is empirical and assumes that the shear resistance is derived from a shear capacity acting uniformly over the effective area of the section considered.

Posttensioning can lead to uplift of concrete slabs as the strand straightens during stressing [7]. While this can reduce self-weight deflections, it can also raise the slab above its supports, particularly for a 2-way spanning plate [8]. A posttensioned slab can also be subject to slippage during stressing which, with inadequate lateral restraint (adjacent slabs and/or masonry walls), can also change the support conditions [9]. As the effect of this is difficult to notice on site, it can result in increased cracking and reduced performance due to these thinner slabs with reduced reinforcement $[10,11]$.

The experimental section that follows demonstrates the effect of posttensioning slippage on 2-way spanning spans subject to point loads compared with traditional flexural and punching shear reinforcement.

\section{Experimental Programme}

Three $1100 \times 1100 \times 140 \mathrm{~mm}$ thick concrete slabs were cast for testing. Slabs S1-S3 assessed the performance under central point loads in terms of strain, deflection, and crack pattern analysis The reinforcement details in the three slabs accounted for a two-way spanning plate with $\mathrm{S} 1$ and without S2 punching shear rebar. Slab S3 did not contain punching shear reinforcement as the intention is to determine how effective posttensioning rebar was at reducing this mode of 


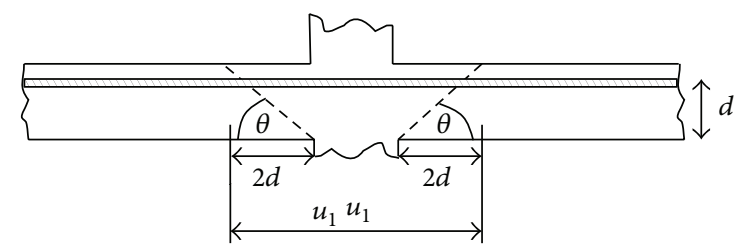

FIGURE 1: Distance of control perimeter from loaded face [2].
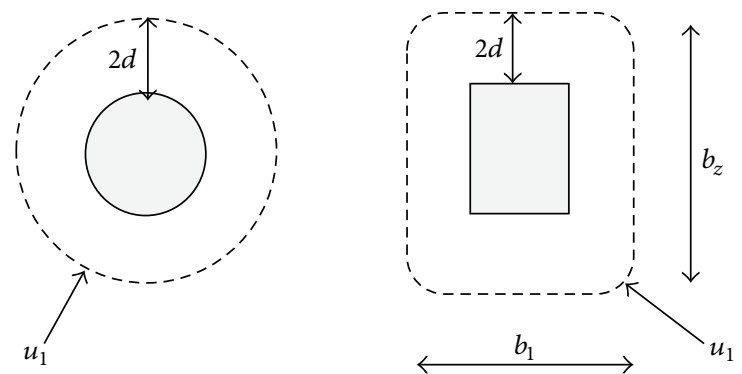

FIGURE 2: Critical control perimeter for columns with different cross sections [1].

TABLE 1: Mix proportions.

\begin{tabular}{lcccc}
\hline \multicolumn{5}{c}{ Mass of ingredients $\left(\mathrm{kg} / \mathrm{m}^{3}\right)$} \\
Water & CEM I & FA & $10 \mathrm{~mm}$ & $20 \mathrm{~mm}$ \\
\hline 225 & 500 & 605 & 445 & 445 \\
\hline
\end{tabular}

FA: fine aggregate; CA: course aggregate.

failure. The support conditions of the test rig were provided a simply supported 2-way spanning arrangement. Figure 3 shows the $100 \times 150 \times 8 \mathrm{~mm}$ RHS frame used to support the slabs during testing.

2.1. Mix Proportions. The concrete for this study included CEM I cement $\left(500 \mathrm{~kg} / \mathrm{m}^{3}\right)$ complying with [12] was used as the cementitious material with a fixed water to cement $(\mathrm{w} / \mathrm{c})$ ratio of 0.45 . Both the fine and coarse aggregates were obtained from local sources in Ireland. The fine aggregate used was medium graded sand and the coarse aggregate was crushed limestone with a maximum size of $20 \mathrm{~mm}$. Before mixing, the water absorption of the aggregates was determined and the water added to the concrete was adjusted accordingly to cater for this.

Following a number of trial mixes, the final proportions were determined so that a slump between 100 and $150 \mathrm{~mm}$ (S3 class slump) [13] could be achieved. The mix proportions are summarised in Table 1.

2.2. Concrete Manufacture. The concrete was manufactured using a pan mixer. For each mix, one slab $(1100 \times 1100 \times$ $140 \mathrm{~mm})$, three cubes $(150 \times 150 \times 150 \mathrm{~mm})$, and two $100 \mathrm{~m}$ diameter $\times 200 \mathrm{~mm}$ long cylinders were cast. Each mix had a volume of $0.20 \mathrm{~m}^{3}$ including $10 \%$ for wastage. After mixing, the concrete was poured in $50 \mathrm{~mm}$ thick layers into the moulds with each layer vibrated on a vibrating table for
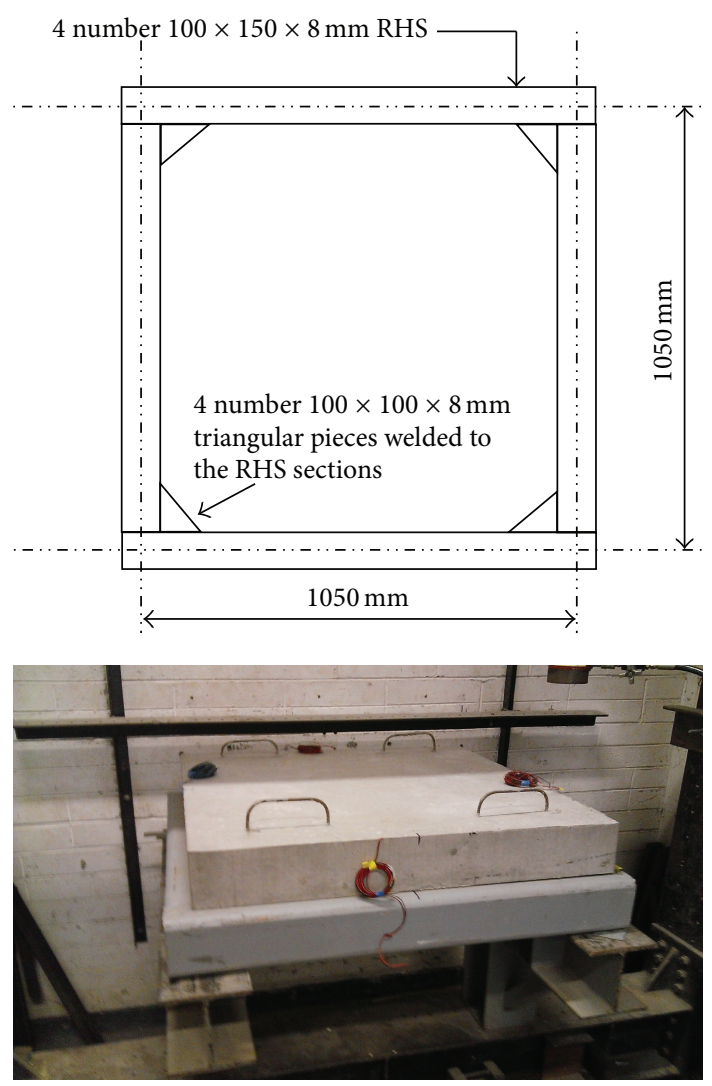

FIGURE 3: RHS frame used to support the concrete slabs.

a time until no more air bubbles were visible on the surface. Curing of the concrete was provided by placing a polythene sheet over the specimens for 24 hours to trap moisture that evaporates from the surface. Following demoulding, the slabs were wrapped in wetted tarp and stored in a laboratory at $20 \pm 3^{\circ} \mathrm{C}$ until testing. The cubes and cylinders were placed in water in a curing tank at $20( \pm 1)^{\circ} \mathrm{C}$ until testing.

2.3. Workability. The workability (i.e., consistence) of the concrete was measured immediately after its manufacture in terms of slump in accordance with [14].

2.4. Compressive Strength. The compressive strength was determined by crushing three $150 \mathrm{~mm}$ cubes at 7 days for each mix in accordance with BS EN 12390-3 for testing hardened concrete [15]. Seven days was chosen as the age to test the slabs as it is a typical to apply posttensioning along with a minimum compressive strength of $25 \mathrm{~N} / \mathrm{mm}^{2}$.

2.5. Tensile Strength. The indirect tensile strength was determined by splitting two $200 \mathrm{~mm}$ cylinders (100 $\mathrm{mm}$ diameter) at 7 days for each mix in accordance with [16].

2.6. Reinforcement Details. Figures $4-6$ and Table 2 summarise the strain gauge locations. Longitudinal reinforcement $(6 \mathrm{~mm}$ diameter) strain gauges were placed on the steel reinforcement just off midspan in both orthogonal 


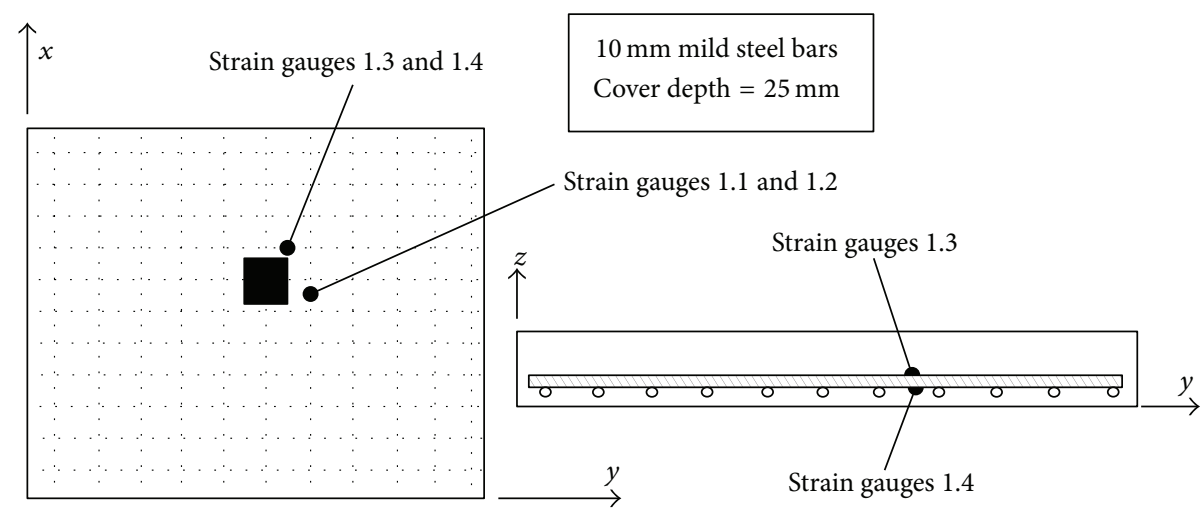

FIgURE 4: Reinforcement details and location of strain gauges 1.1 to 1.4 in slab S1.

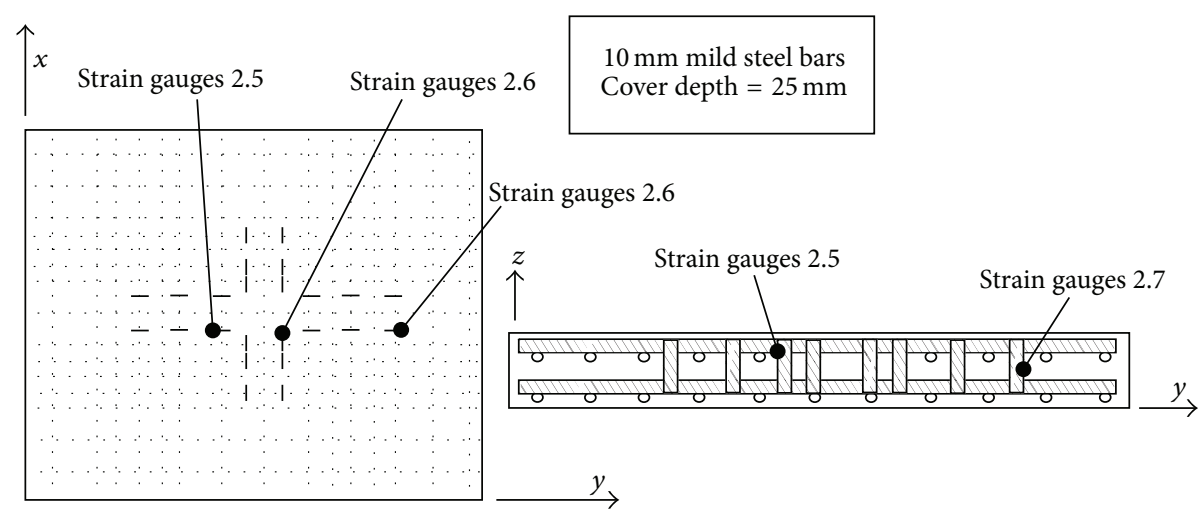

FIgURE 5: Reinforcement details and location of strain gauges 2.5 to 2.7 in slab S2 (gauges 2.1 to 2.4 are identical to 1.1 to 1.4 in slab S1).

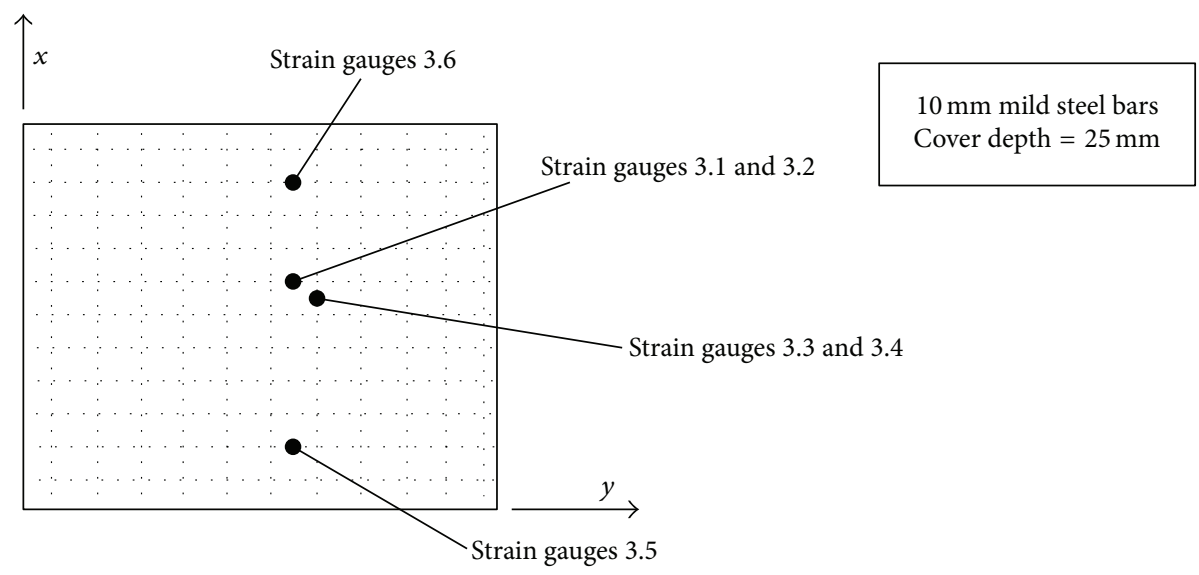

FIGURE 6: Reinforcement details and location of strain gauges 3.1 to 3.6 in slab S3.

directions on all slabs. To increase the accuracy of the strain readings and assess the degree of bending occurring in the reinforcement, two gauges were placed on the top and bottom of each reinforcing bar.

Strain gauges were also placed on one shear link leg ( $6 \mathrm{~mm}$ diameter $\times 100 \mathrm{~mm}$ long) in slab S2 (2.5 and 2.7) on each layer to assess their stress profile during loading. Two extra longitudinal reinforcement strain gauges were placed on a reinforcing bar in the top flexural steel layer of at either end of the posttensioned slab (slab S3) to determine the effect of stressing on the longitudinal reinforcement. The strain gauges were fitted onto the steel by sanding the bars, polishing them using a degreaser and applying using fast drying super glue. Lead wires were soldered to the terminal and multiple layers of protective varnish applied. An example of a prepared strain gauge on the steel is shown in Figure 7.

Seven Linear Variable Displacement Transducers (LVDT) where placed on the soffit of each slab to record 
TABLE 2: Steel strain gauge label and position.

\begin{tabular}{|c|c|c|}
\hline $\begin{array}{l}\text { Strain } \\
\text { gauge } \\
\text { label }\end{array}$ & $\begin{array}{l}\text { Slab } \\
\text { number }\end{array}$ & Strain gauge position \\
\hline 1.1 & \multirow{4}{*}{ S1 } & Top of $x$-direction flexural reinforcement \\
\hline 1.2 & & $\begin{array}{l}\text { Bottom of } x \text {-direction flexural } \\
\text { reinforcement }\end{array}$ \\
\hline 1.3 & & Top of $y$-direction flexural reinforcement \\
\hline 1.4 & & $\begin{array}{l}\text { Bottom of } y \text {-direction flexural } \\
\text { reinforcement }\end{array}$ \\
\hline 2.1 & \multirow{7}{*}{ S2 } & Top of $x$-direction flexural reinforcement \\
\hline 2.2 & & $\begin{array}{l}\text { Bottom of } x \text {-direction flexural } \\
\text { reinforcement }\end{array}$ \\
\hline 2.3 & & Top of $y$-direction flexural reinforcement \\
\hline 2.4 & & $\begin{array}{l}\text { Bottom of } y \text {-direction flexural } \\
\text { reinforcement }\end{array}$ \\
\hline 2.5 & & Leg of link in perimeter 1 \\
\hline 2.6 & & Leg of link in perimeter 2 \\
\hline 2.7 & & Leg of link in perimeter 3 \\
\hline 3.1 & \multirow{8}{*}{ S3 } & Top of $x$-direction flexural reinforcement \\
\hline 3.2 & & $\begin{array}{l}\text { Bottom of } x \text {-direction flexural } \\
\text { reinforcement }\end{array}$ \\
\hline 3.3 & & Top of $y$-direction flexural reinforcement \\
\hline 3.4 & & $\begin{array}{l}\text { Bottom of } y \text {-direction flexural } \\
\text { reinforcement }\end{array}$ \\
\hline 3.5 & & $\begin{array}{l}\text { Top of } x \text {-direction flexural reinforcement } \\
\text { (L2) }\end{array}$ \\
\hline 3.6 & & $\begin{array}{l}\text { Bottom of } x \text {-direction flexural } \\
\text { reinforcement (R2) }\end{array}$ \\
\hline$x 1-4$ & & Top face of concrete $x$-direction \\
\hline$y 1-4$ & & Top face of concrete $y$-direction \\
\hline
\end{tabular}

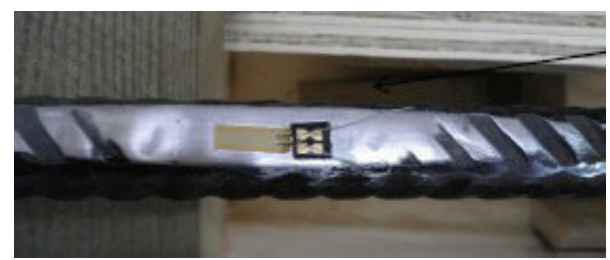

FIGURE 7: Strain gauge attached to an embedded steel bar.

the deflections during loading and to locate the punching shear perimeter (Figures 8 and 9) [17]. One additional LVDT was placed in the centre of slab S3 (PL) during stressing to record the effect of prestressing on the deflection shows the LVDT arrangement in all three slabs. Figure 10 shows the LVDT arrangements on the top surface of each slab.

2.7. Posttensioning Ducts. Test specimen $\mathrm{S} 3$ was designed and tested as an unbonded posttensioned slab. The strands used for the prestressing procedure were isolated from the concrete during both casting and testing using $20 \mathrm{~mm}$ diameter plastic ducting (Figure 11) which was inserted into preformed holes cut into the formwork.

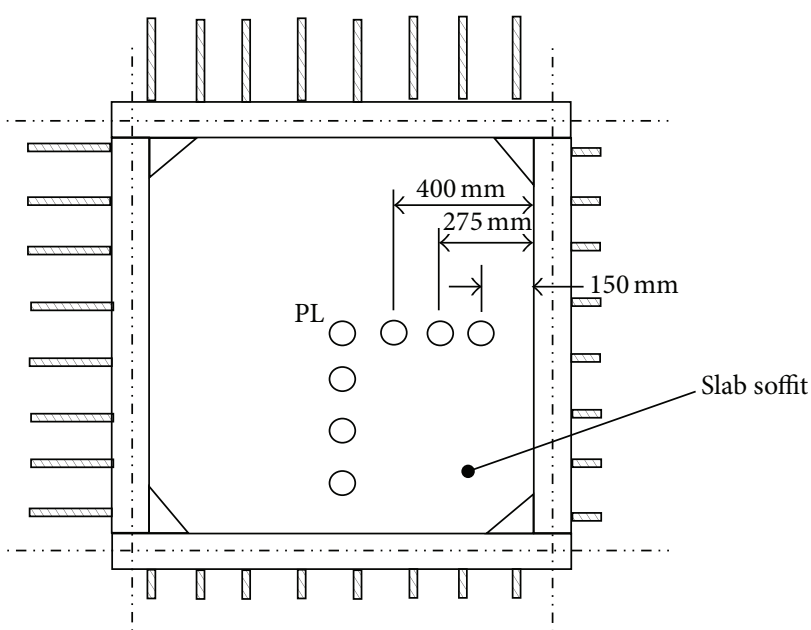

FIGURE 8: LVDT arrangements on the soffit of all slabs.

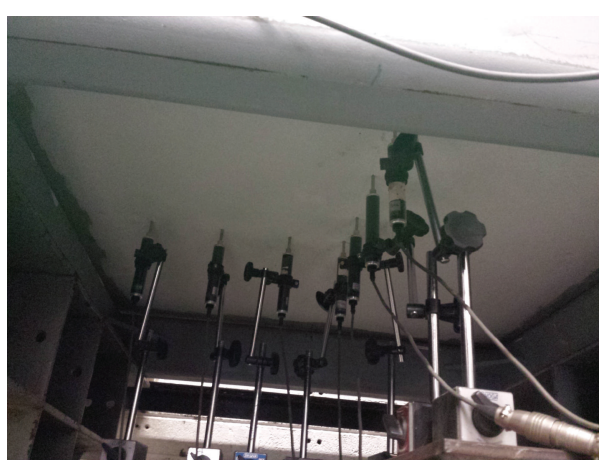

FIGURE 9: LVDTs positioned on the soffit of each slab.

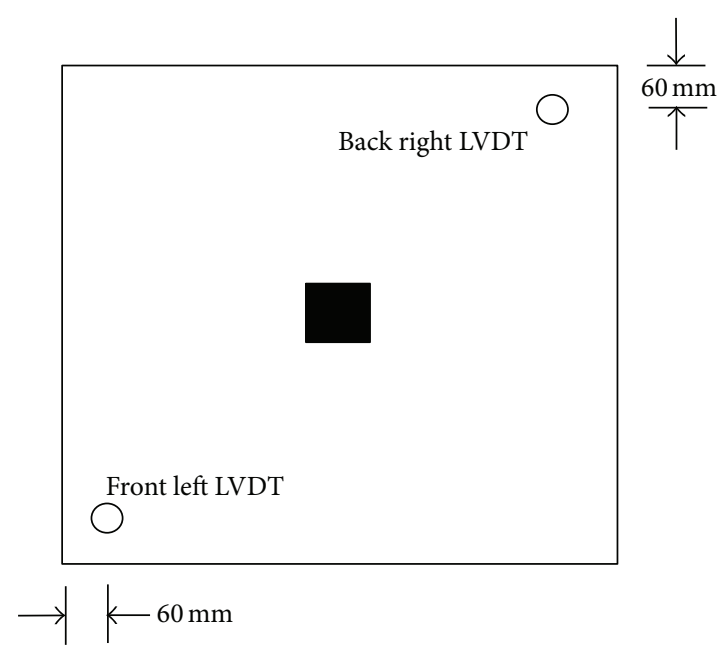

FIgURE 10: LVDT's locations on the top of all slabs.

Each slab was cast with four $8 \mathrm{~mm}$ diameter lifting eyes (Figure 12) to aid movement. Each eye was lapped $200 \mathrm{~mm}$ under the top layer of flexural reinforcement and protruded $90 \mathrm{~mm}$ above the surface of the concrete. 


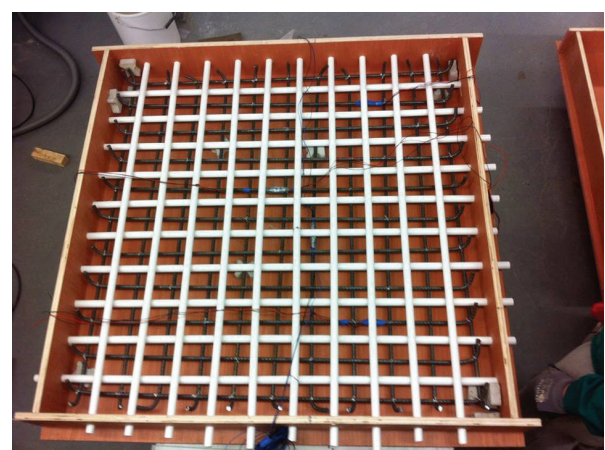

FIGURE 11: PVC duct locations prior to casting.

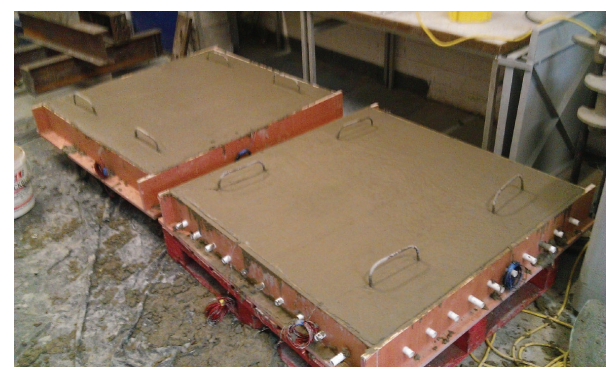

FIGURE 12: Lifting eye positioned during casting.

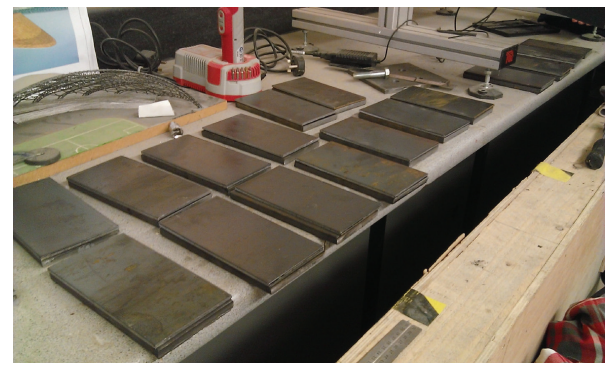

FIGURE 13: Steel bearing plates prior to drilling.

2.8. Posttensioning Bearing Plates. To distribute the compressive forces into slab $S 3$ in a safe and controlled manner a composite $17 \mathrm{~mm}$ thick steel bearing plate (Figure 13) was prepared with two $12 \mathrm{~mm}$ holes to receive the prestressing strands $[18,19]$.

2.9. Prestressing Procedure. Following casting, the PVC ducts were trimmed flush with the side of the concrete face to ensure a flat surface for the steel plates to bear against during stressing. The steel strands were fed through the bearing plates and ducts and a barrel and wedge anchor was fixed at either end. The strand was pulled taught ensuring that any slack was removed [20].

Stressing of the strands was performed using a $25 \mathrm{~T}$ hydraulic monostrand jack, as shown in Figure 14 calibrated to a pressure of 200 Bar equal to a stressing force of $65.1 \mathrm{kN}$ and a stress of $1252 \mathrm{~N} / \mathrm{mm}^{2}$ corresponding to $67 \%$ of the tensile strength of the strand $\left(f_{\mathrm{pk}}=1860 \mathrm{~N} / \mathrm{mm}^{2}\right)$. The jack was placed onto the "live" end of the strand (Figures 15 and 16)

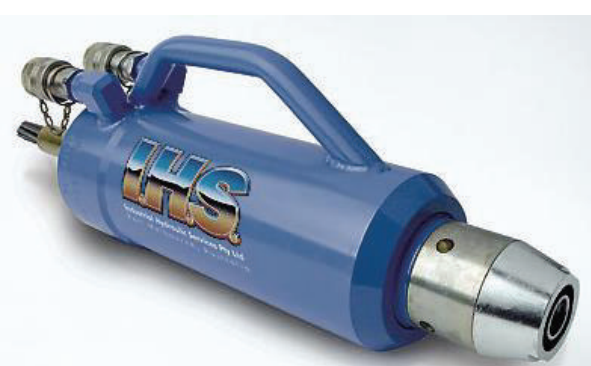

FIGURE 14: 25T hydraulic monostrand jack.

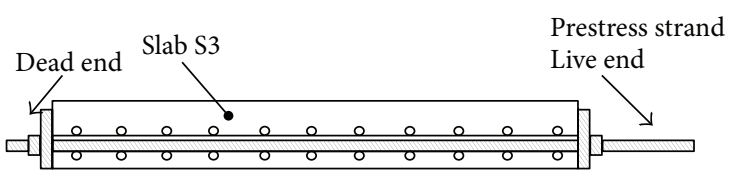

FIGURE 15: Dead and live end anchor.

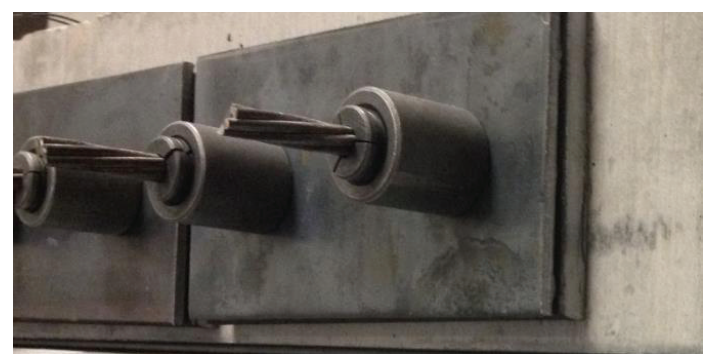

FIGURE 16: Live end anchor.

and prevented from moving at the opposite end by the "dead end" anchor. Once the stressing jack reached a pressure of 200 Bar, jacking stopped.

As ten 10 strands were to be stressed in both orthogonal directions, a logical stressing plan was employed to account for effects of elastic deformation as the posttension force is applied on the level of prestress transferring into the slab. With multiple strands, stressing the first does not cause any losses as, although the concrete undergoes shortening, the jack is not removed until the specified (calibrated) value of prestress is applied therefore negating any elastic deformation. However, stressing the 2nd strand does cause a loss in force in the former due to concrete shortening. If the stressing procedure took place in a sequential manner the losses in prestress force due to elastic deformation in the strands would range from zero in the final strand stressed to maximum in the first.

Therefore, the strands were stressed in a "skipped" fashion $[19,20]$ with the second one to be tensioned was furthermost from the previous. The next strand prestressed was adjacent to strand 1 and so on until all 20 were stressed. The methodology is shown in Figure 17.

Furthermore, the strands parallel to the $x$-axis were tensioned first before those parallel to the $y$-axis as these were located at a smaller eccentricity. The readings these strain gauges were used to confirm the effects of the tensioning on the strands in the concrete member. 


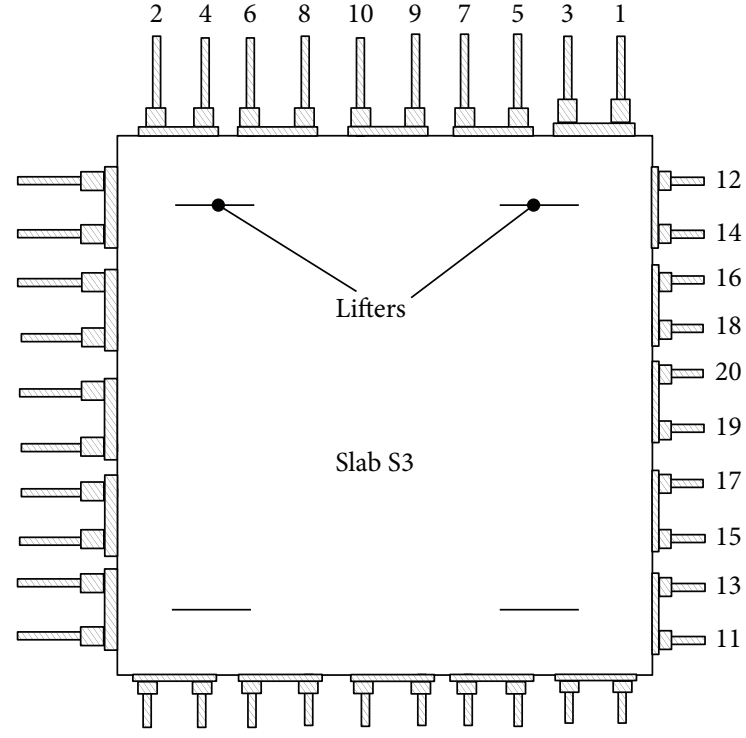

FIGURE 17: Stressing procedure.

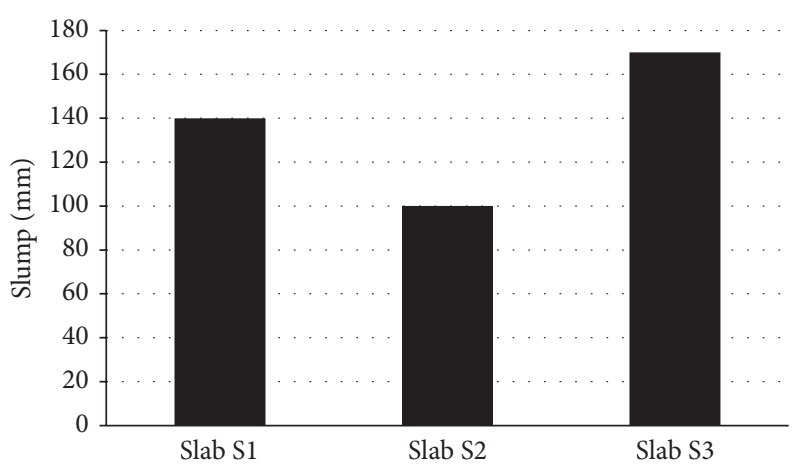

FIGURE 18: Slump values.

\section{Discussion of Results}

3.1. Workability. The slump values recorded are shown in Figure 18 which shows the required workability (100$150 \mathrm{~mm}$ ) was achieved in all the concrete cast. Concrete mix S3 had a slightly higher slump than the others but in conjunction with the compressive and strength results (Figure 18) it is clear that it had no significant effect.

3.2. Compressive Strength. The compressive strength results are presented in Figure 19. As shown, the entire concrete cast achieved the characteristic strength specified $\left(35 \mathrm{~N} / \mathrm{mm}^{2}\right)$. There is a slight decrease in strength for slab S3 which corresponds to the higher slump result for that mix (Figure 18) which may indicate excess water added in error. However, as the design strength was achieved the concrete was deemed satisfactory.

3.3. Tensile Strength. The tensile strengths are presented in Figure 20. As shown, all concretes achieved a minimum tensile strength of $3.0 \mathrm{~N} / \mathrm{mm}^{2}$. As with the compressive

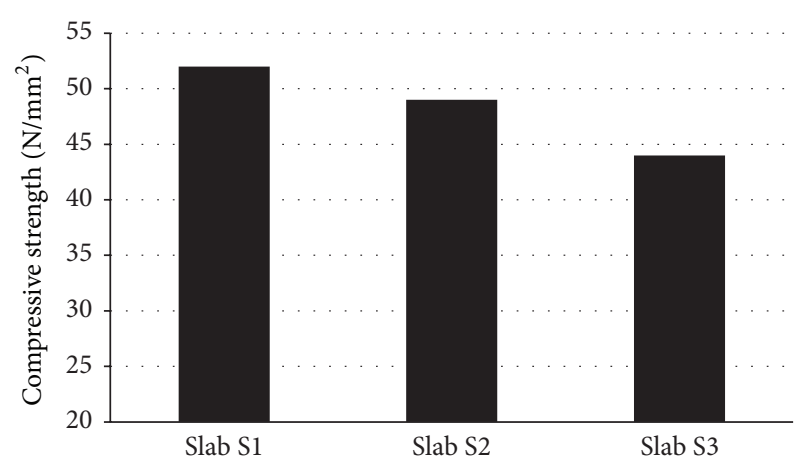

FIGURE 19: Compressive strength results.

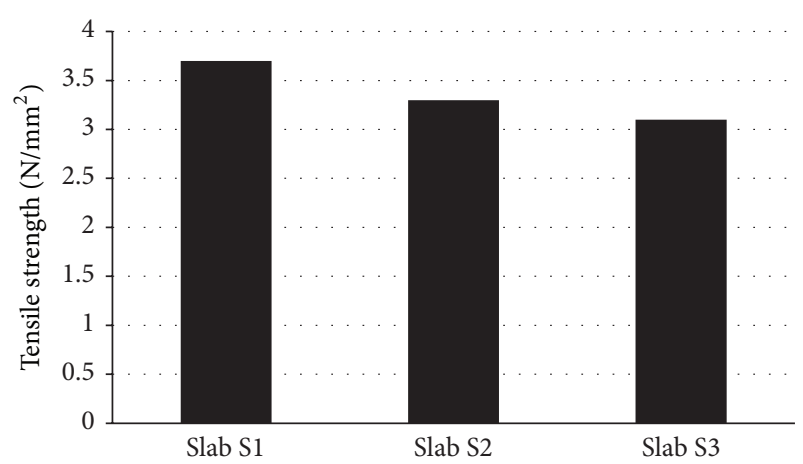

FIgURE 20: Tensile strength results.

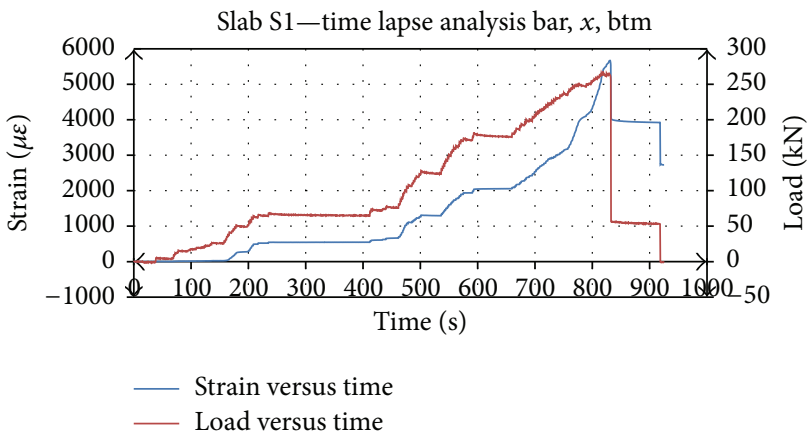

FIgURE 21: Strain time lapse analysis for gauge 1.2, slab S1.

strength, the tensile strength for slab S3 was slightly lower than the others.

\subsection{Slab S1 Results}

3.4.1. Strain Analysis. Failure of slab S1 occurred at a load of $256 \mathrm{kN}$. The predicted failure load (using [3]) was $201 \mathrm{kN}$. The strain gauge results are shown in Figures 21-23 with gauge 1.1 braking during testing.

Figure 21 shows the increase in strain in gauge 1.2 with load in the bottom of the flexural reinforcement $(x, \mathrm{btm})$ indicating the rebar contribution to the load carrying capacity of the slab. At $40 \mathrm{kN}$, increases in strain in the top bar of the flexural reinforcement ( $y$, top, parallel to the $y$ direction) were observed (Figure 22) and are lower due to 


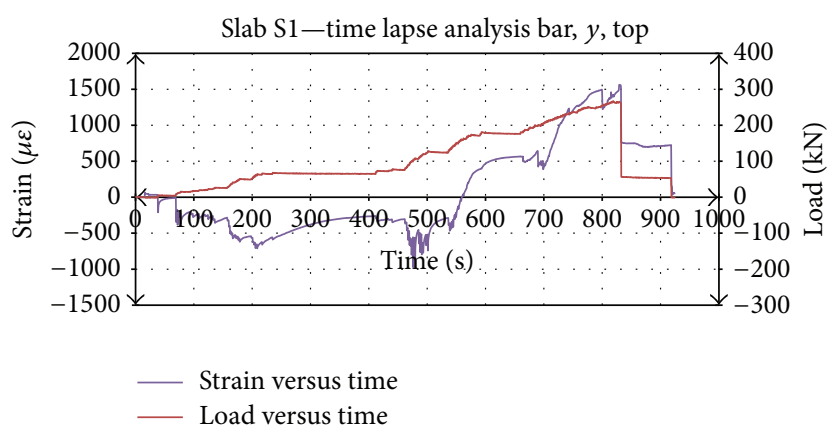

Figure 22: Strain time lapse analysis for gauge 1.3, slab S1.

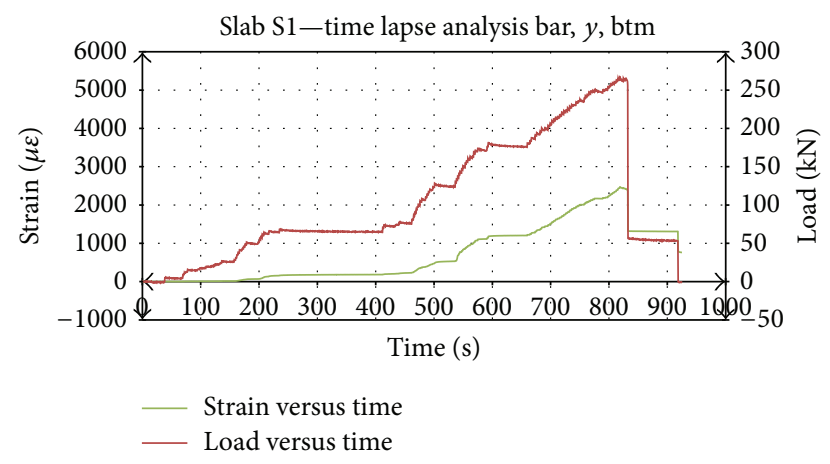

FIGURE 23: Strain time lapse analysis for gauge 1.4, slab S1.

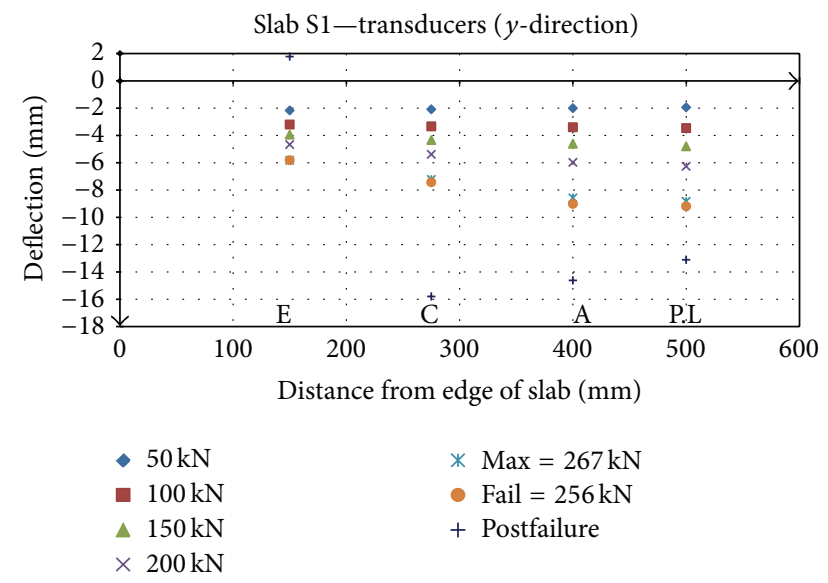

FIGURE 24: Deflection V's distance from support ( $y$-direction).

local compression. It is not until $160 \mathrm{kN}$ that a compressive strain is recorded. At $40 \mathrm{kN}$, the strain in the bar increased linearly until approximately $3200 \mu \varepsilon$ corresponding to a load of $240 \mathrm{kN}$ where the bar began to yield.

3.4.2. Flexurally Reinforced Concrete Slab S1: Deflections. The deflections at reference points A-F are shown in Figures 24 and 25. At "postfailure," the instant after failure, the LVDT deformations indicate considerable deflection. However, the deflection at point $\mathrm{E}$ has decreased indicating that the punching shear critical perimeter is located between points $\mathrm{C}$

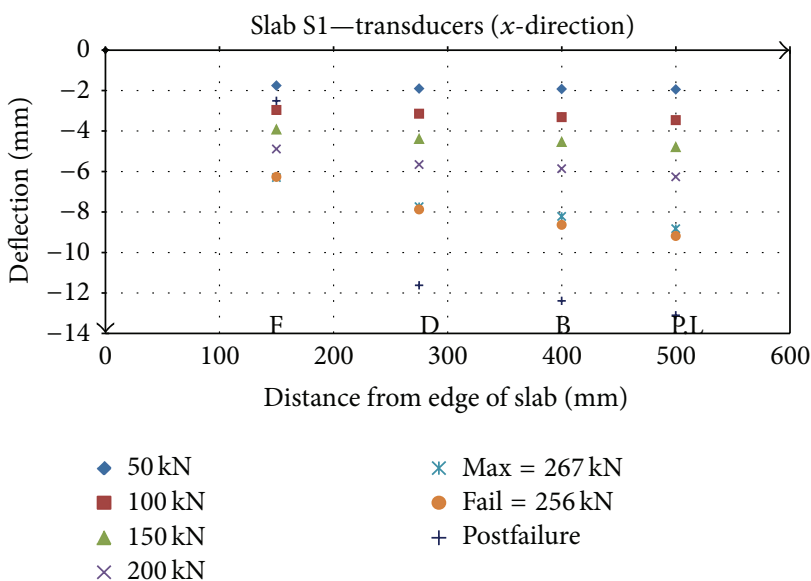

Figure 25: Deflection V's distance from support ( $x$-direction).

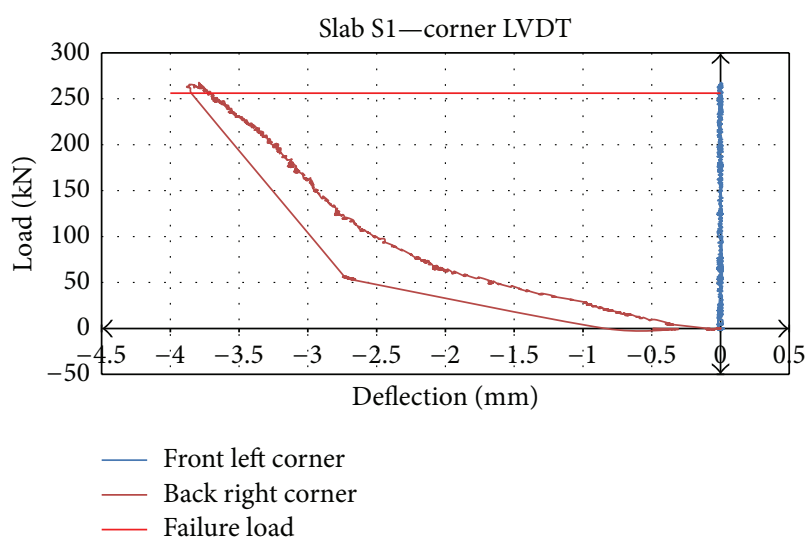

Figure 26: Load V's corner deflection on slab S1.

and E. Eurocode recommendations propose that the critical perimeter to be checked at a distance $2 d$ from the loaded area which relates to $210 \mathrm{~mm}$ from the loaded area or $240 \mathrm{~mm}$ from the supported edge here [21].

A similar deflection pattern can be seen in Figure 25. Again, at postfailure, the deflections at $\mathrm{B}$ and $\mathrm{D}$ increase considerably while at $\mathrm{F}$, it decreases indicating that the critical perimeter for punching is located at a distance between $150 \mathrm{~mm}$ to $275 \mathrm{~mm}$. The LVDT readings on the top surface are shown in Figure 26 where negative deflection indicating slab uplift. As may be seen, the results demonstrate an uplift of $3.8 \mathrm{~mm}$ at the back right corner of the slab at the failure load $(256 \mathrm{kN})$.

3.4.3. Crack Pattern Analysis. Figure 27 shows the post failure crack patterns on the underside of the slab. As indicated, a clear well defined punching shear perimeter is visible with the failure perimeter passing between LVDT locations $\mathrm{C}$ and $\mathrm{E}$ confirming the deformations as seen in Figures 24 and 25. 


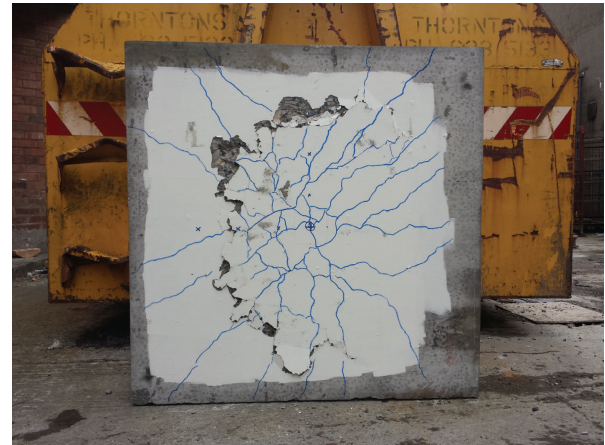

FiguRE 27: Crack pattern on Soffit of slab S1.

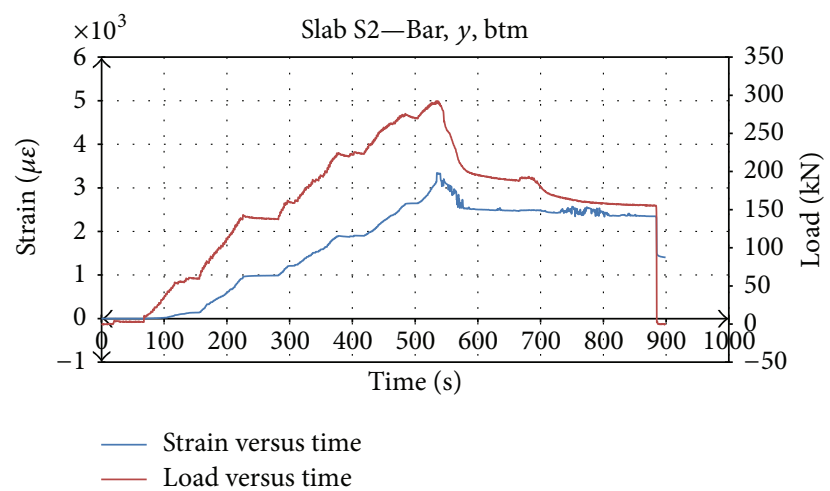

FIgURE 28: Time lapse for gauge 2.2 on Bar, $y$, btm.

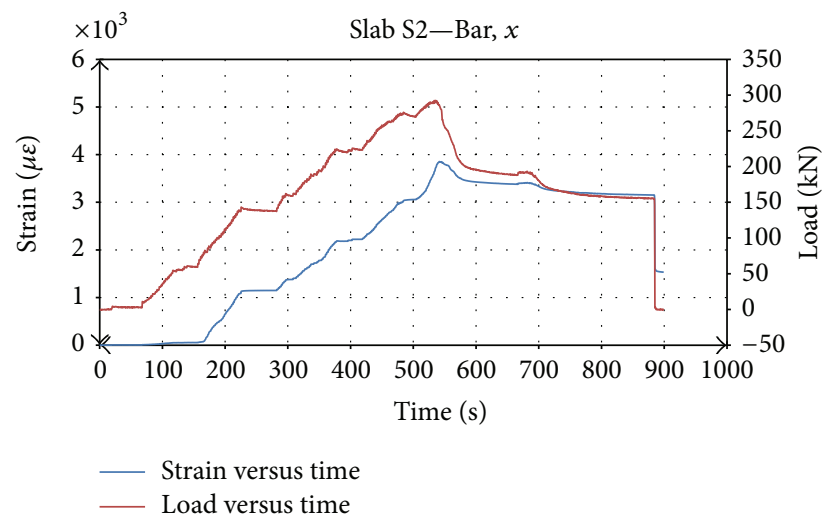

Figure 29: Time lapse for gauges on Bar, $x$.

\subsection{Slab S2 Results}

3.5.1. Failure Load Analysis: Slab S2. Failure of Slab S2 occurred at a load of $293 \mathrm{kN}$ due to its inability to sustain load after this point. The theoretical punching failure load for this test specimen was calculated as $278 \mathrm{kN}$ (using $\mathrm{cl}$ 6.4.5(1) Expression 6.52 [1]).

3.5.2. Strain Gauge Analysis. The results from strain gauges 2.2-2.4 are shown in Figures 28 and 29. As may be seen, the strain in gauge $x$ (Bar, $y$ ) increases with load until the failure load $(293 \mathrm{kN})$ is reached. The trend of strain increases

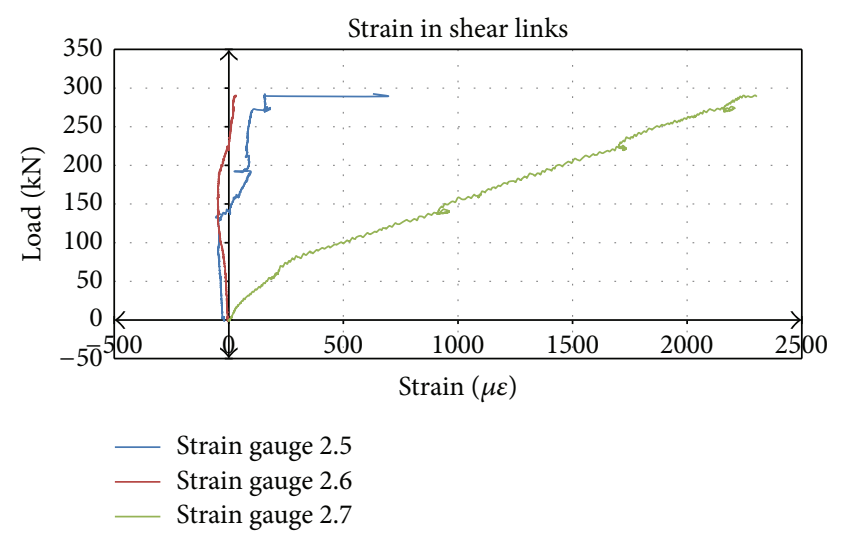

FIGURE 30: Strain readings recorded on shear links.

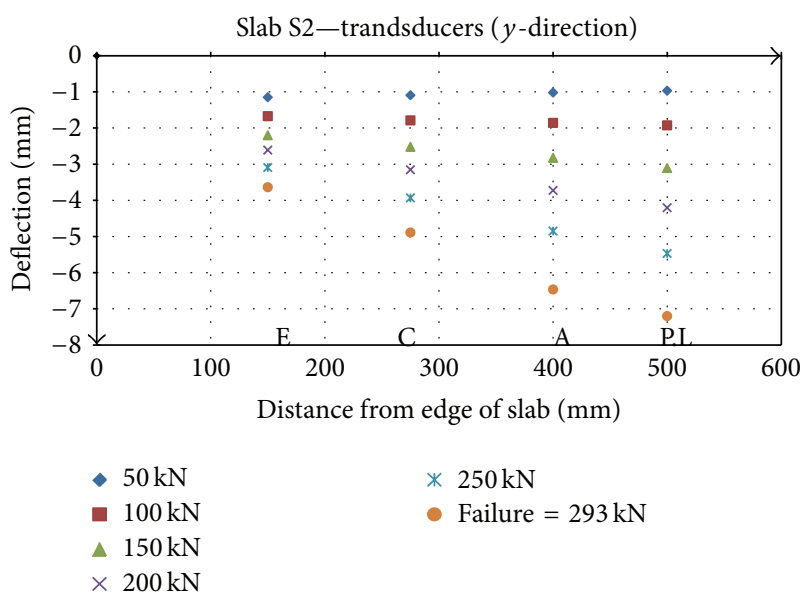

FIGURE 31: Transducer displacements ( $y$-direction).

confirms that the bar passed through the elastic range where strain increases faster than the applied load until approximately $3000 \mu \varepsilon$ where the bar behaves plastically.

Also shown is a change in strain at approximately $80 \mathrm{kN}$, where the first crack occurred. A linear increase of strain occurs in the bar until approximately $280 \mathrm{kN}(3200 \mu \varepsilon)$ where the reinforcement is assumed to have yielded.

3.5.3. Shear Link Strain Gauges. The strain readings for gauges 2.5 to 2.7 on links L1 to L3, respectively, are shown in Figure 30. As may be seen, a shear force was experienced by the concrete and its tensile capacity was exceeded. Links crossing cracks contributing to the capacity of the section indicating that the links experienced a tensile stress and positive strain. Link L3 experienced the greatest positive strain. Link L2 experienced a negative strain until a load of $225 \mathrm{kN}$ was applied.

3.5.4. Deformation Analysis: Soffit of Slab. Figures 31 and 32 show the deflections at locations A-F from zero at the supported edge to maximum at the centre $(7.2 \mathrm{~mm}$ at $293 \mathrm{kN})$ suggesting the slab was failing in flexure. 


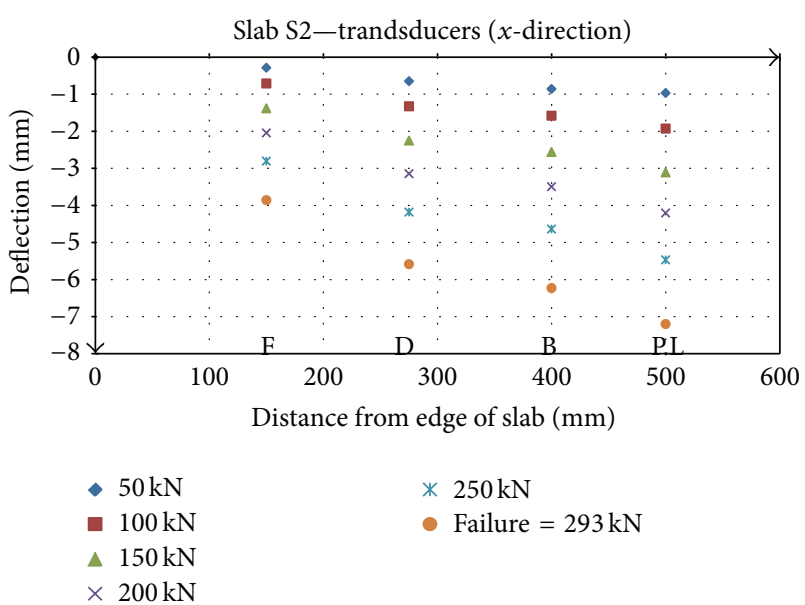

Figure 32: Transducer displacements ( $x$-direction).

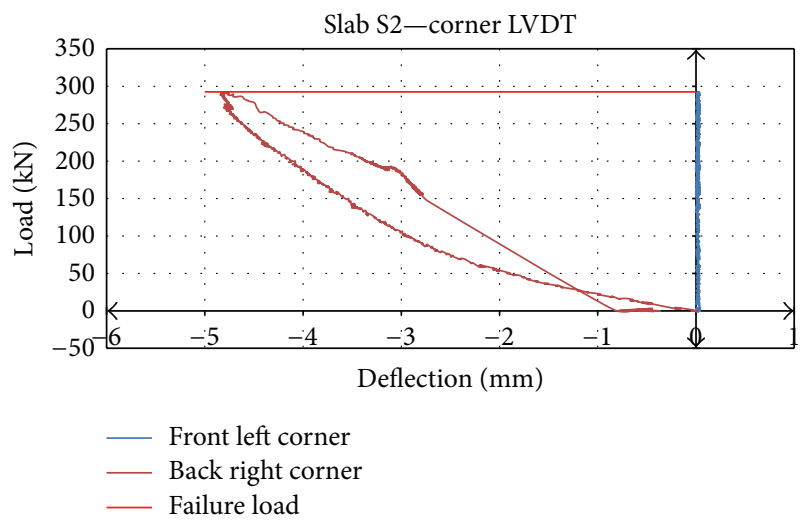

Figure 33: Slab S2-load V's corner deflection.

3.5.5. Deformation Analysis: Top Surface. Figure 33 shows that the deflections from the top surface are similar to those seen in slab S1 with no uplift at the front left corner.

3.5.6. Crack Pattern Analysis. The crack pattern for Slab S2 postfailure is shown in Figure 34. The slabs failing in punching shear within the loaded area (perimeter $\mathrm{P}, \mathrm{Q}, \mathrm{R}, \mathrm{S}$ ) and the cracks formed part of one long flexural crack. Although cracks were initiated by a flexural mechanism, the capacity of the cracked surface reduced leading to the formation of punching shear cracks.

\subsection{Slab S3 Results}

3.6.1. Tensioning Analysis. The short-term loss of prestress and subsequent force transfer to the concrete section was determined by attaching eight strain gauges to the top surface of the six connected to four reinforcing bars in the flexural steel.

3.6.2. Concrete Strain Gauge Analysis. The strands parallel to the slabs $x$-direction were tensioned first (Figure 35) with the effect shown in Figure 36. As expected gauge $x_{1}$,

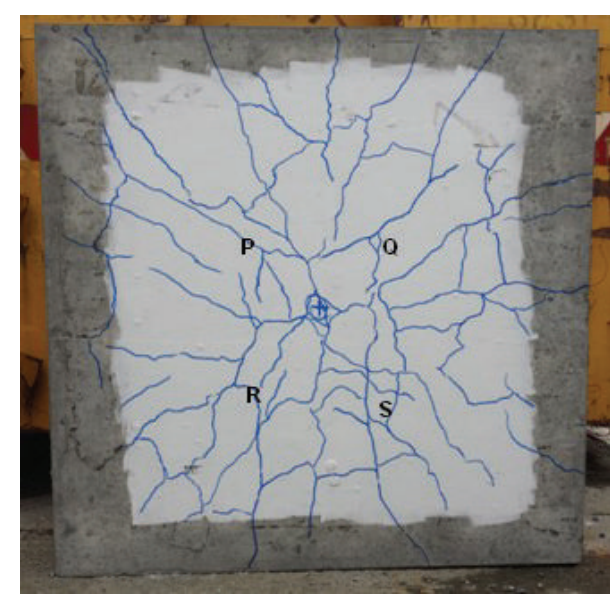

FIGURE 34: Crack pattern on soffit of slab S2.

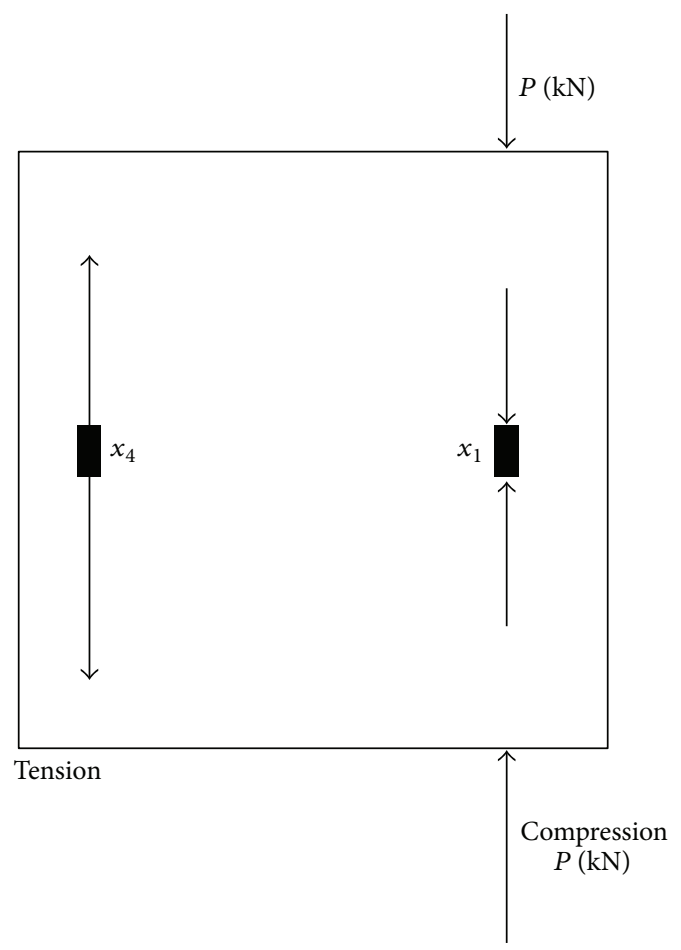

Figure 35: Behaviour of slab during Event 1.

located directly above the position of strand 1, experienced the greatest compressive strain as a result of the applied axial load during tensioning of strand one. It appears that gauges $x_{3}$ (top) and $x_{4}$ (below) experienced a small tensile strain. Therefore, although the slab was in compression in the vicinity located adjacent to the stressed strand, tension was induced on the slab at locations $x_{3}$ and $x_{4}$ (Figure 36).

The second strand tensioned was directly beneath gauge $x_{4}$. The effects of tensioning on the strains of gauges $x_{1}$ to $x_{4}$ are shown in Figure 37. As may be seen, the gauge located on top of the strand being tensioned is undergoing increases in compressive strain while the two gauges located furthest away are exhibiting tension. In addition to providing 


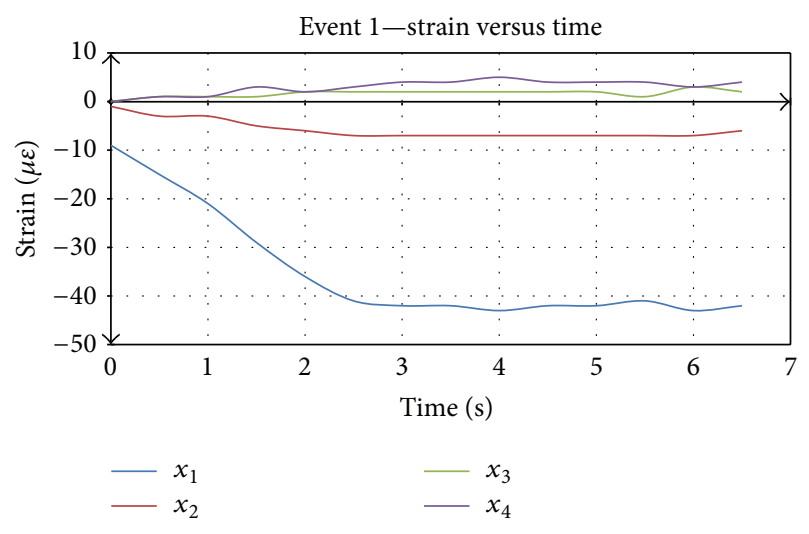

FIGURE 36: Strains parallel to applied axial compression.

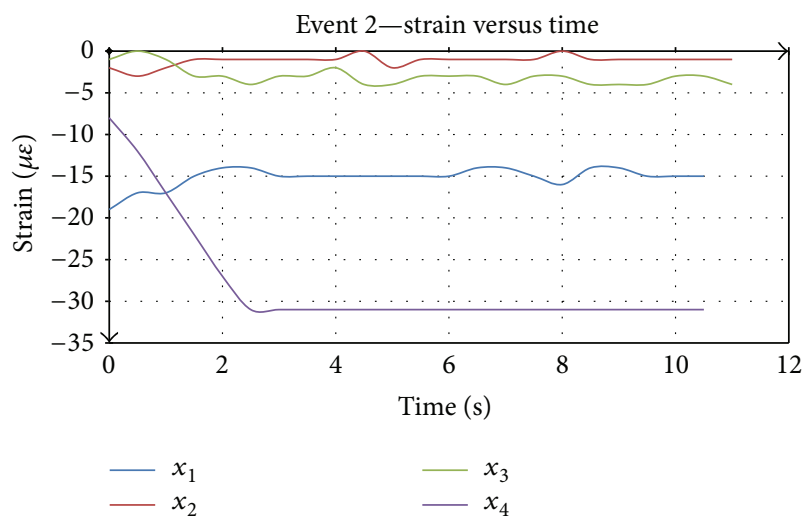

FIGURE 37: Strains parallel to applied axial compression.

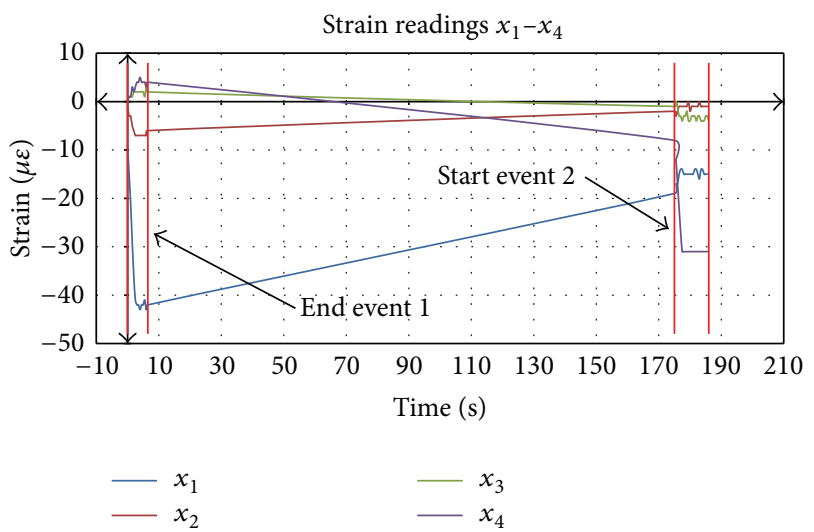

Figure 38: Strain reading $x_{1}$ to $x_{4}$-end Event 1 to start Event 2.

information on the effect in the slab during stressing, the strain gauges parallel to the direction of stressing highlight a loss in prestress force that occurs in the concrete immediately after the end of an event, that is, the removal of the stressing jack. The losses which occur between the end of Event 1 and the start of Event 2 are represented by the changing strain readings for gauges $x_{1}$ to $x_{4}$.

Immediately following the end of Event 1 , strain gauge $x_{1}$ reads a compressive strain of $43 \mu \varepsilon$ (Figure 38). By the time

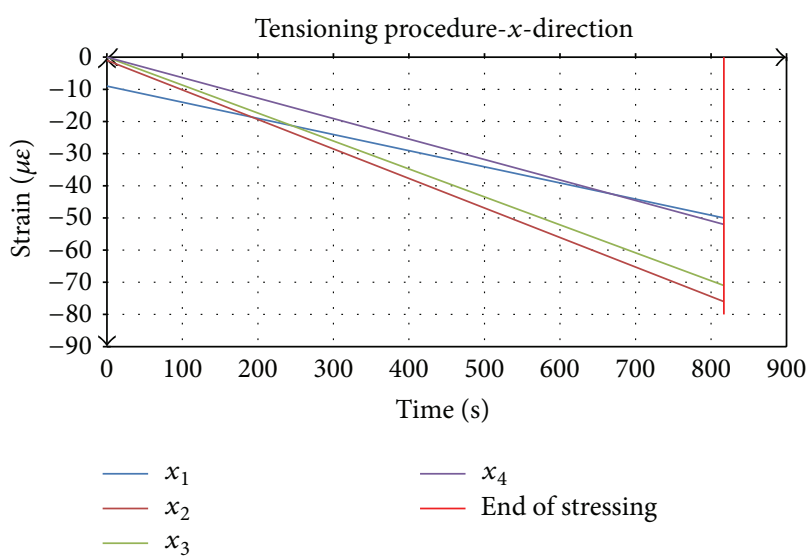

FIgURE 39: Total increase in strain in direction $x$.

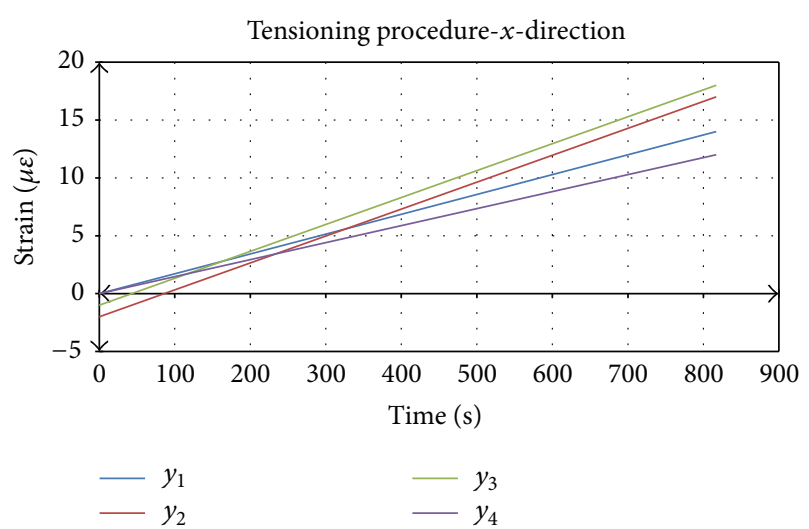

FIgURE 40: Total increase in strain in direction $y$.

tensioning of strand two took place, that is, the start time of Event 2, this compressive strain decreased to $19 \mu \varepsilon$. This suggests that the concrete surrounding strand 1 is experiencing a smaller compressive stress at the time of stressing strand two than at the end of Event 1. There has been a significant loss in prestress force from the end of Event 1 until the stressing of strand two takes place. The most likely cause of this loss in prestress force is as a result of anchorage draw-in losses which have been discussed previously.

Figure 39 shows the total increase in strain on gauges $x_{1}$ to $x_{4}$ over the time taken to tension all ten strands in the $x$ direction. As may be seen, the highest compressive strains occurred at locations $x_{2}$ and $x_{3}$ which was expected due to the sequence of tensioning undertaken.

Four gauges were located perpendicular to the direction of stressing during Events 1-10. The strains recorded in Figure 40 show tensile strains occur in gauges $y_{1}$ to $y_{4}$ with the maximum occurring in gauges $y_{2}$ and $y_{3}$. By applying the compressive force in the $x$-direction the axial shortening in the direction of stressing is accompanied by a lateral elongation, that is, expansion normal to the applied load. Assuming the concrete slab was acting as an uncracked section, the magnitude of this lateral expansion can be attributed to Poisson's ratio. 


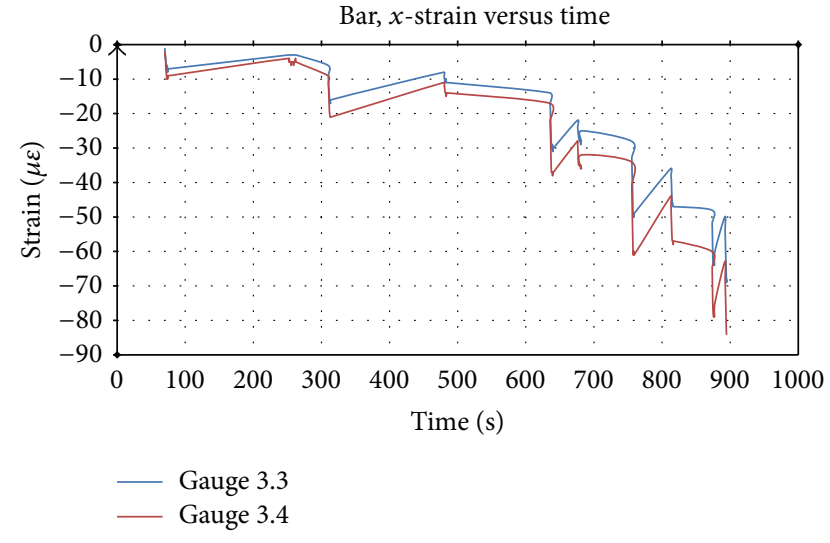

FIgURE 41: Bar, $x$ strain in gauges 3.3 and 3.4.

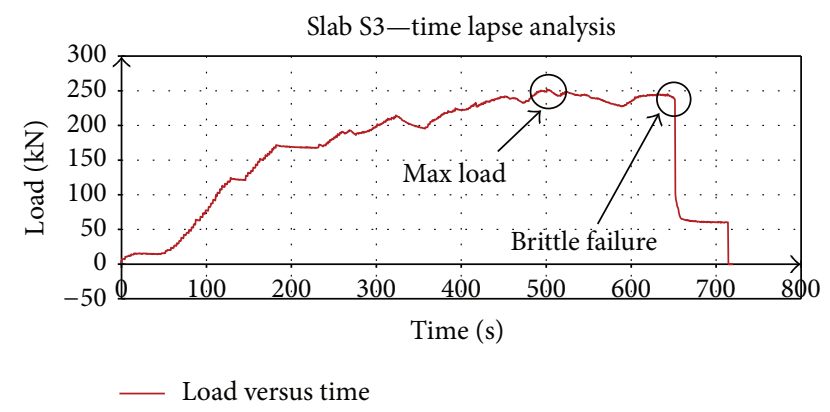

Figure 42: Load V's time slab S3.

3.6.3. Steel Strain Gauges. The strains in the four flexural reinforcement bars within slab S3 are shown in Figure 41. As shown, there is a clear loss in strain within the bars during the changeover period between tensioning the strands indicating a loss in prestressing force and in the compression force applied to the slab.

3.6.4. Failure Load Analysis. The failure load of Slab S3 was $252 \mathrm{kN}$ (Figure 42). Upon reaching this load, the slab failed in a brittle manner.

3.6.5. Strain Gauge Analysis. Strain Gauges 3.3 and 3.4 located on Bar, $y$ exhibit much larger strains than those on Bar, $x$ (3.1 and 3.2) as shown in Figure 43. First cracking occurred parallel to the slabs $x$-direction at a load of $90 \mathrm{kN}$. The first crack passed the steel reinforcement at a load of $150 \mathrm{kN}$. However, upon reaching failure, the strains in Bar, $y$ are three times greater than those in Bar, $x$. Figures 43 and 44 both indicate that neither bar had yielded which is unexpected considering that once the maximum load had been reached, the slab was unable to sustain any increase in load.

3.6.6. Deformation Analysis: Deformation Results-Soffit of Slab. Figures 45 and 46 show the deflections in the $y$ - and $x$-directions, respectively. As may be seen, the deflections in the two directions are not consistent with what would be expected for a 2-way spanning slab. Comparing the various

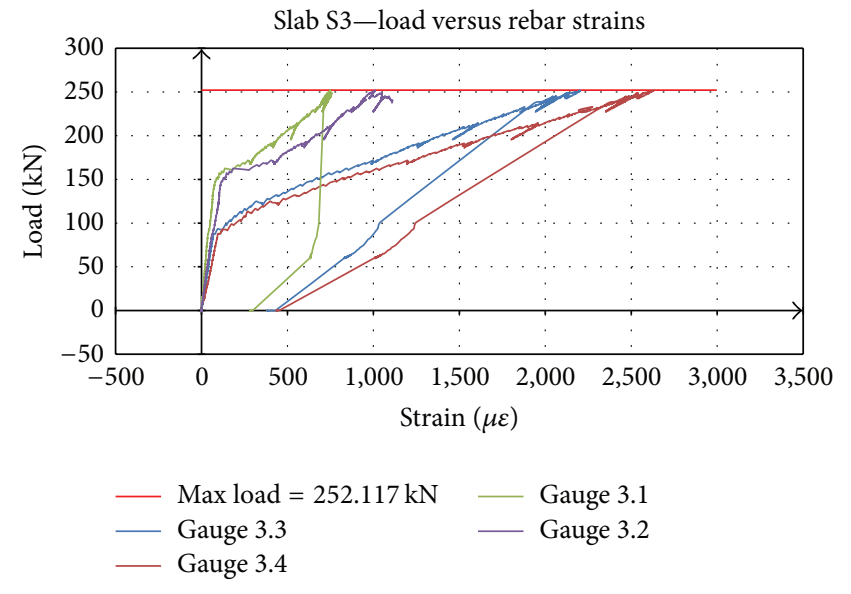

FIGURE 43: Load V's strain (gauges 3.1-3.4).

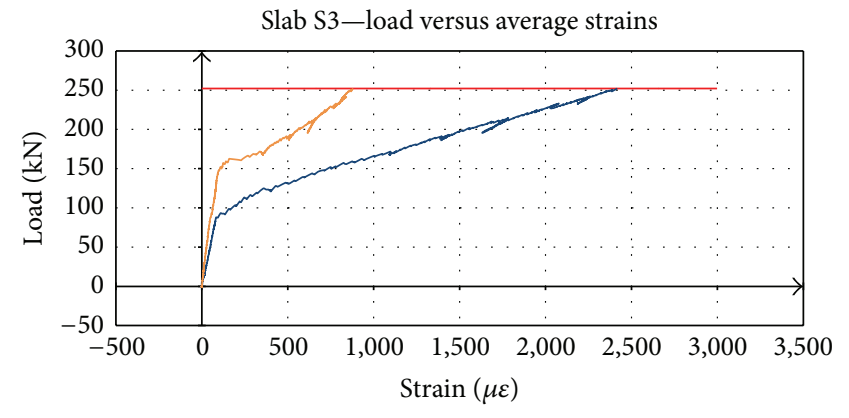

- Max load $=252.117 \mathrm{kN}$
- Average 3.3 and 3.4
Average 3.1 and 3.2

FIgURE 44: Load V's strain (average readings).

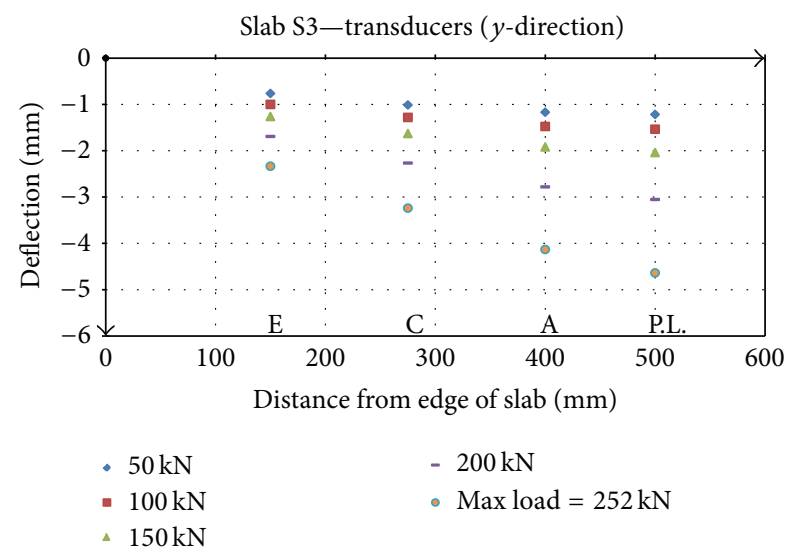

Figure 45: Transducer displacements (P.L., A, C, E).

LVDTs along the two orthogonal directions there noticeable differences between the magnitude of deflection. The vertical deflection recorded decreases from a maximum underneath the point of application to the slabs. The deflections along the $x$-direction indicate the slab was deflecting as one-way spanning. This suggests that slab S3 during testing following 


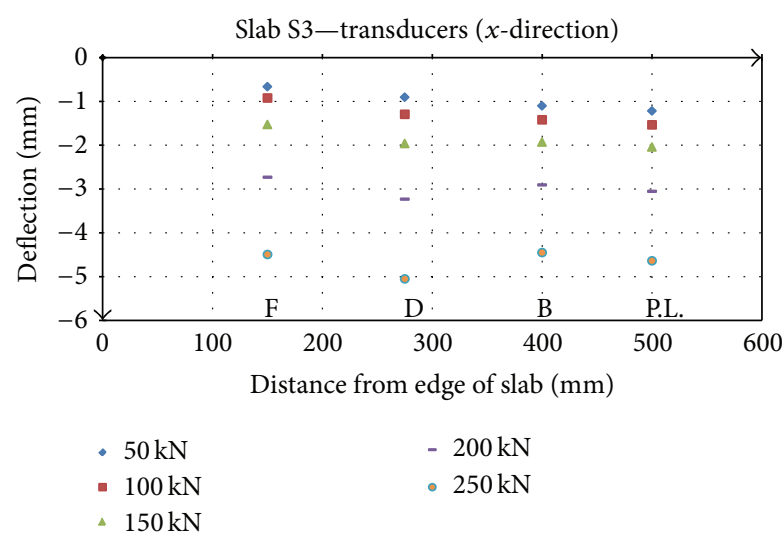

Figure 46: Transducer displacements (P.L., B, D, F).

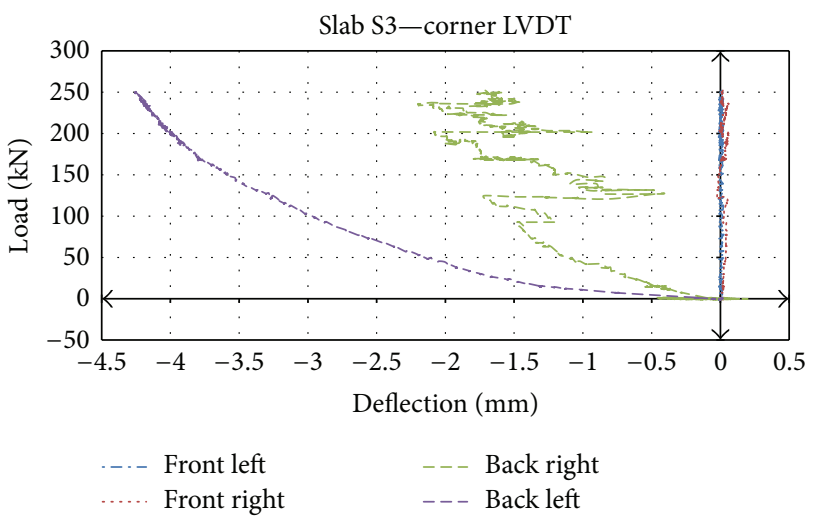

FIGURE 47: Slab S3-load V's corner deflection.

posttensioning had marginally less support along the slabs $y$ direction.

3.6.7. Deformation Analysis: Top Surface. Figure 47 indicates that there was no uplift in both the front left and front right corners with uplift occurring in the back left and, to a lesser extent, at the back right corner.

3.6.8. Crack Pattern Analysis. Figure 48 shows the crack pattern on the soffit of the slab post failure. The first crack to form was along FDB. Only minor cracking occurred along points ECA. The brittle failure crack shown occurred at a load of $236 \mathrm{kN}$ and the soffit of the slab punched through along the top edge.

3.7. Comparison of Results between Slabs S1-S3. The loads at failure were 256,293 , and $252 \mathrm{kN}$ for slabs S1-S3, respectively. While the punching shear reinforcement did yield a higher load capacity in slab S2, the effect of slippage in S3 created a 1way spanning system with a reduction in capacity. The mode of failure also confirms this with a brittle, sudden collapse behaviour observed in S1 and S3 with punching through the slab while flexural was observed in S2. The strain behaviour

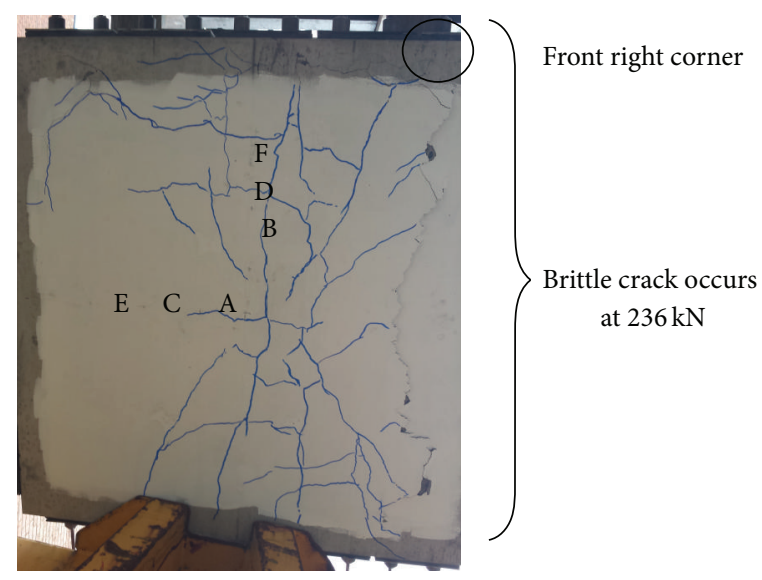

FIGURE 48: Crack pattern on failure surface of slab S3.

in the reinforcement in $\mathrm{S} 1$ suggests the bars yielded under the loading point and while this would be expected in S3 due to the creation of a 1-way spanning slab and the brittle failure mechanism, this was not the case.

The deflections in S1 and S3 showed failure by punching through the concrete. S2, again, demonstrated flexural behaviour with the maximum deflection occurring centrally. The clearly defined crack patterns in both S1 and S3 indicate punching shear perimeters. S2, however, did not yield a well-defined crack pattern with good dispersal and ring-like concentrations under the load. Although they were initiated by a flexural mechanism, the capacity of the cracked surface reduced leading to the formation of punching shear cracks.

\section{Conclusions}

The following conclusions from the work above are summarized below.

The exact location of the critical punching shear perimeter is specified as being located a distance of $2 d_{\text {avs }}$ from the face of the loaded area. The results here, in terms of both the deflection and crack pattern analysis for slab S1, show that this perimeter is accurate.

The punching shear resistance of the slab without shear reinforcement (S1) yielded a conservative load estimate of $201 \mathrm{kN}$ in comparison with the experimental failure load of $256 \mathrm{kN}$ which questions the reliability of the method for small cross-sectional slab depths.

The introduction of an external axial force has enhanced both the flexural and shear capacity of the section.

The support condition has an effect on the results. While the support rig used here was adequate to resist the forces applied to it, care must be taken during testing to ensure the support conditions accurately simulate the conditions designed for.

Although the benefit of prestressing has been shown, the measurement of force transfer and subsequent loss in force is a difficult task and extra attention should be paid to these crucial factors. 


\section{Conflict of Interests}

The authors declare that there is no conflict of interests regarding the publication of this paper.

\section{References}

[1] Eurocode 2: Design of concrete structures, 2004.

[2] BS 8110, Structural use of concrete, 1997.

[3] IS Eurocode 2: Design of concrete structures, 2008.

[4] Comite Euro-International du Beton, Ceb-Fip Model Code 1990: Design Code, Comite Euro-International du Beton, 1993.

[5] A. Muttoni and J. Schwartz, Behaviour of Beams and Punching in Slabs without Shear Reinforcement, vol. 62, IABSE Colloquium, Zürich, Switzerland, 1991.

[6] P. E. Regan and M. W. Braestrup, "Punching shear in reinforced concrete," Bulletin d'Information no. 168, BED, 1985.

[7] T. H.-K. Kang and J. W. Wallace, "Punching of reinforced and post-tensioned concrete slab-column connections," ACI Structural Journal, vol. 103, no. 4, pp. 531-540, 2006.

[8] D. A. Foutch, W. L. Gamble, and H. Sunidja, "Tests of posttensioned concrete slab-edge column connections," ACI Structural Journal, vol. 87, no. 2, pp. 167-179, 1990.

[9] A. Pavic, P. Reynolds, P. Waldron, and K. J. Bennett, "Critical review of guidelines for checking vibration serviceability of post-tensioned concrete floors," Cement and Concrete Composites, vol. 23, no. 1, pp. 21-31, 2001.

[10] M. Krause, B. Milmann, F. Mielentz et al., "Ultrasonic imaging methods for investigation of post-tensioned concrete structures: a study of interfaces at artificial grouting faults and its verification," Journal of Nondestructive Evaluation, vol. 27, no. $1-3$, pp. 67-82, 2008.

[11] J. S. Lovrovich and D. I. McLean, "Punching shear behaviour of slabs with varying span-depth ratios," ACI Structural Journal, vol. 87 , no. 5, pp. 507-512, 1990.

[12] British Standards Institution, BS EN 197-1, Cement: Composition, Specifications and Conformity Criteria for Common Cements, British Standards Institution, London, UK, 2000.

[13] British Standard Institute, BS EN 206 Part 1, Concrete: Specification, Performance, Production and Conformity, British Standard Institute, 2000.

[14] BS EN 12350-2, Testing fresh concrete: slump-test, 2009.

[15] British Standards Institution, BS EN 12390-3, Testing Hardened Concrete: Compressive Strength of Test Specimens, British Standards Institution, London, UK, 2009.

[16] British Standards Institute, Testing Concrete: Method for Determination of Tensile Splitting Strength, BS 1881-117, British Standards Institute, London, UK, 1983.

[17] K. H. Tan, K. Tong, and C. Y. Tang, "Direct strut-and-tie model for prestressed deep beams," Journal of Structural Engineering, vol. 127, no. 9, pp. 1076-1084, 2001.

[18] T. C. Triantafillou, "Shear strengthening of reinforced concrete beams using epoxy-bonded FRP composites," ACI Structural Journal, vol. 95, no. 2, pp. 107-115, 1998.

[19] A. Marí, E. Mirambell, and I. Estrada, "Effects of construction process and slab prestressing on the serviceability behaviour of composite bridges," Journal of Constructional Steel Research, vol. 59, no. 2, pp. 135-163, 2003.
[20] A. Muttoni, "Punching shear strength of reinforced concrete slabs without transverse reinforcement," ACI Structural Journal, vol. 105, no. 4, pp. 440-450, 2008.

[21] Z. P. Bazant and Z. Cao, "Size effect in punching shear failure of slabs," ACI Structural Journal, vol. 84, no. 1, pp. 44-53, 1987. 

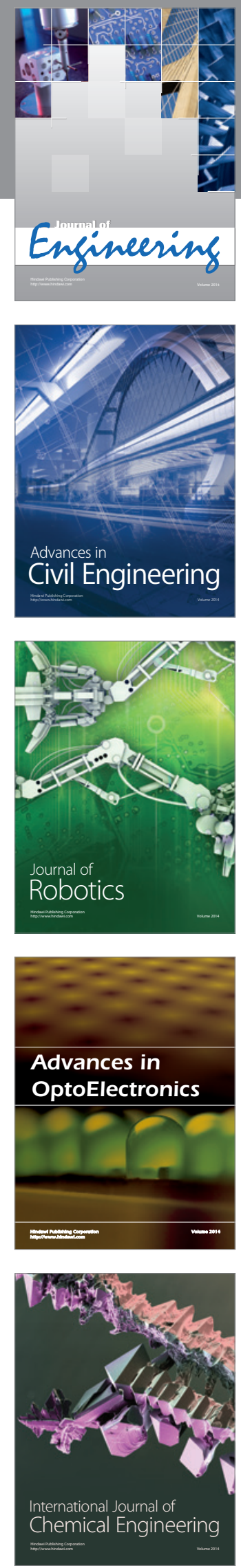

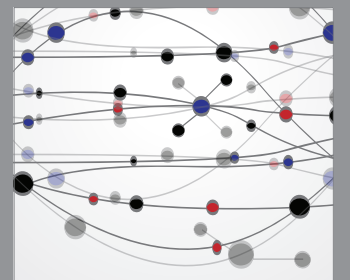

The Scientific World Journal
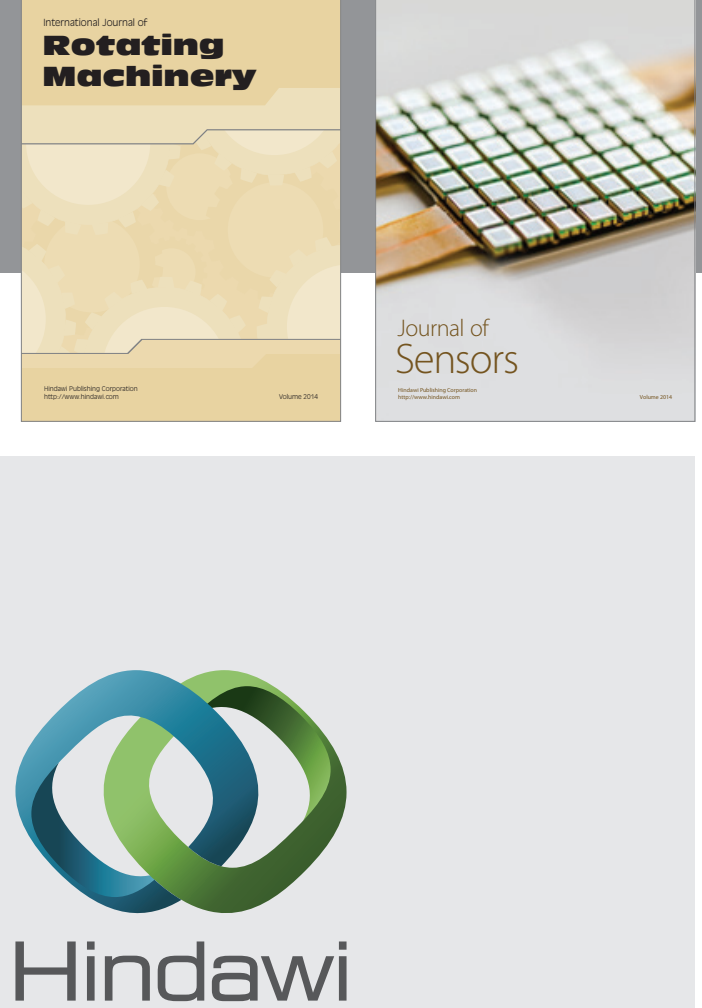

Submit your manuscripts at http://www.hindawi.com
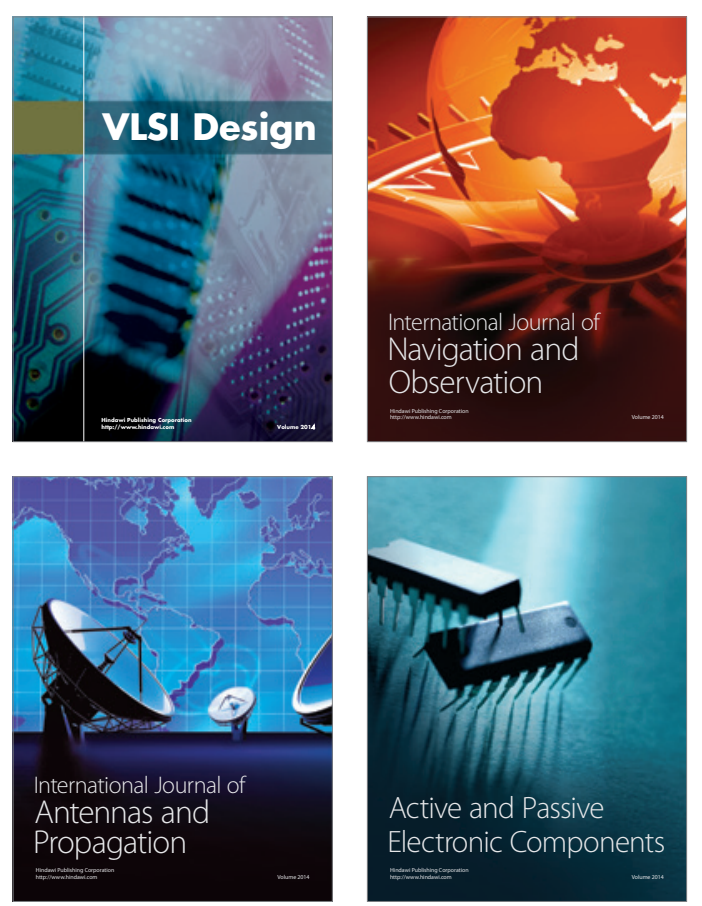
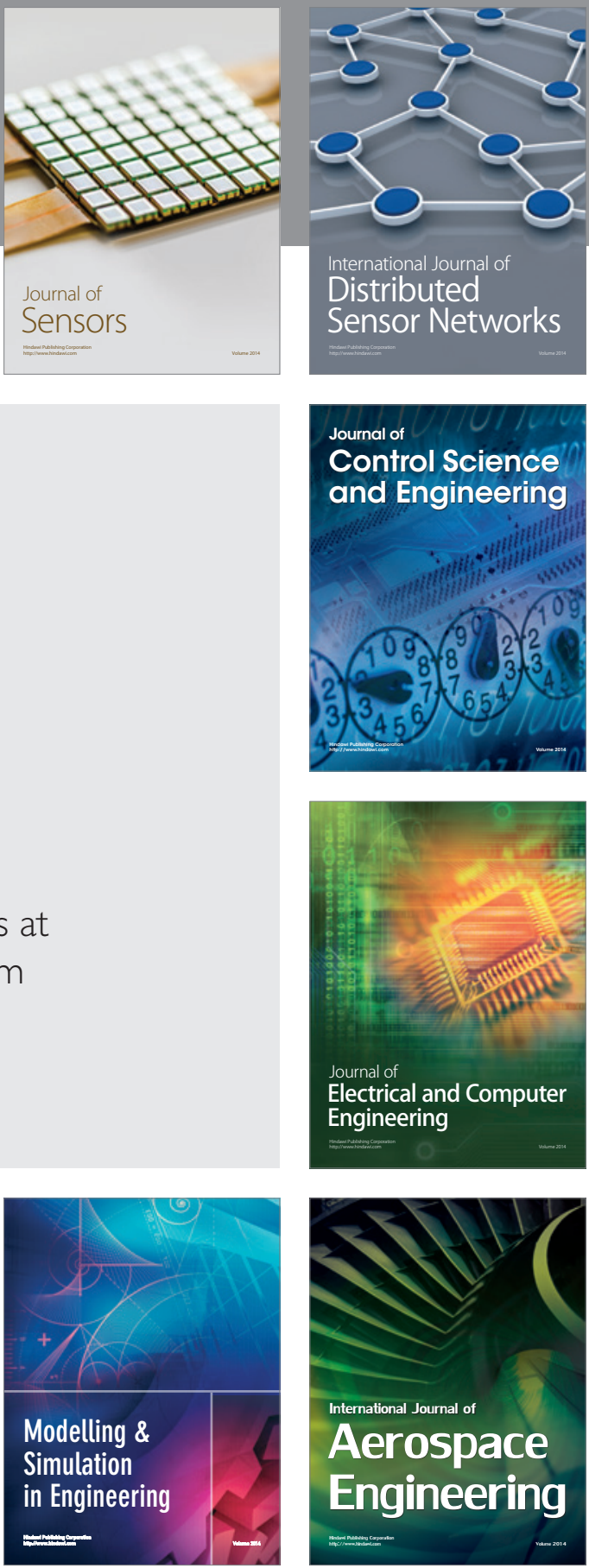

Journal of

Control Science

and Engineering
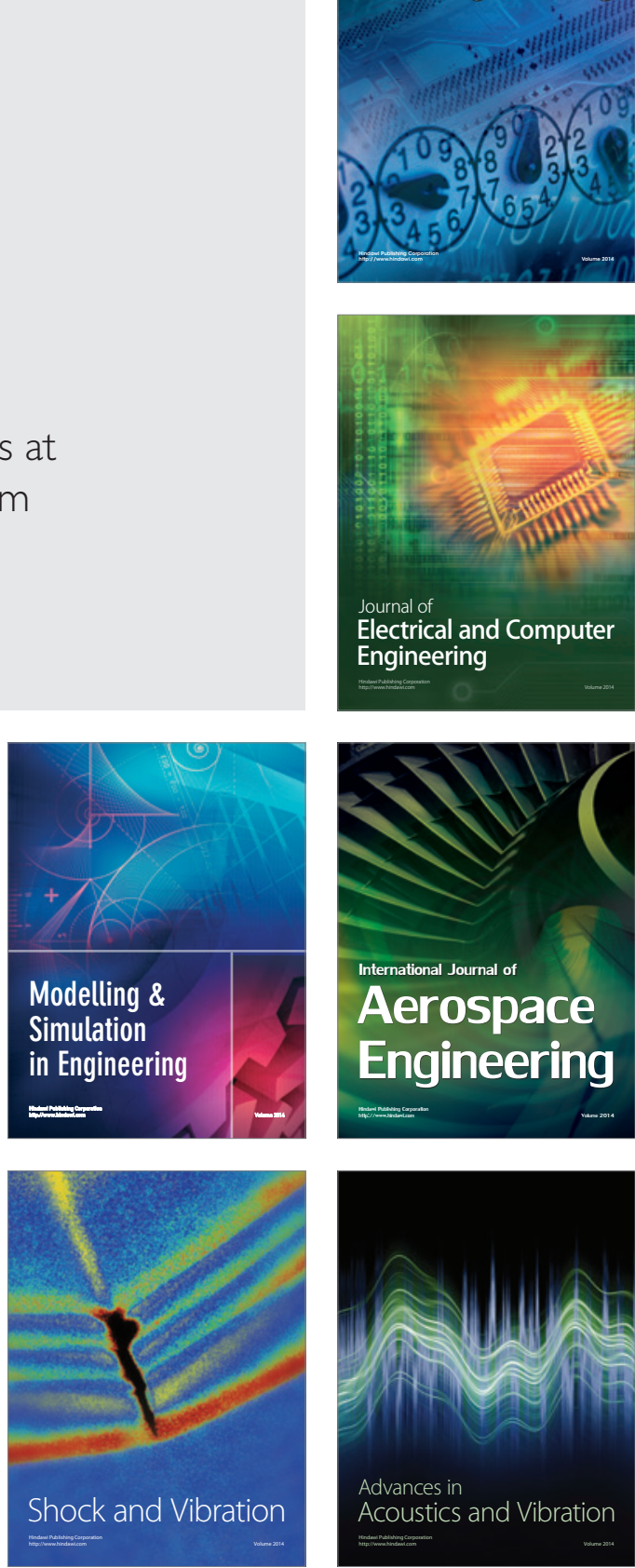